\title{
PERBEDAAN PENINGKATAN KEMAMPUAN BERPIKIR KREATIF MATEMATIS SISWA MENGGUNAKAN MODEL PEMBELAJARAN KOOPERATIF TIPE BERKIRIM SALAM DAN SOAL DENGAN THINK PAIR SHARE DI SMP SWASTA IMELDA MEDAN
}

\author{
Sri Wahyuni Tampubolon, Edi Syahputra \\ Fakultas Matematika dan Ilmu Pengetahuan Alam, \\ Universitas Negeri Medan (UNIMED), 2201 Medan, Sumatera Utara, Indonesia \\ Email: sriwahyuni.tampubolon11@gmail.com
}

\begin{abstract}
ABSTRAK
Penelitian ini bertujuan untuk melihat bahwa terdapat perbedaan peningkatan kemampuan berpikir kreatif matematis siswa menggunakan model pembelajaran kooperatif tipe berkirim salam dan soal dengan model pembelajaran kooperratif tipe Think Pair Share pada materi luas permukaan dan volume kubus dan balok di kelas VIII SMP Swata Imelda Medan T.A 2016/2017. Jenis penelitian ini adalah eksperimen semu. Populasi dalam penelitian ini adalah seluruh siswa kelas VIII Semester II SMP Swasta Imelda Medan yang terdiri dari 4 kelas dengan jumlah keseluruhan siswa 136 orang. Pengambilan sampel dilakukan dengan cara simple random sampling dengan mengambil 2 kelas dari 4 kelas secara acak yaitu kelas eksperimen 1 yang berjumlah 30 orang dan kelas eksperimen 2 yang berjumlah 34 orang. Instrumen yang digunakan untuk mengetahui kemampuan berpikir kreatif matematis siswa adalah tes kemampuan berpikir kreatif yang telah divalidasi dalam bentuk uraian. Dari hasil penelitian yang diberikan perlakuan yang berbeda, kelas eksperimen 1 dengan model pembelajaran kooperatif tipe berkirim salam dan soal dan kelas eksperimen 2 dengan model pembelajaran kooperatif kooperratif tipe Think Pair Share diperoleh nilai rata-rata kelas eksperimen 1 sebesar 34,375 dan nilai rata-rata kelas eksperimen 2 sebesar 25,368. Hasil uji $t 2$ arah dengan $d k=62$ dan $\alpha=0,05$, diperoleh $t_{\text {hitung }}=2,073$ dan $t_{\text {tabel }}=1,669$ sehingga $-t_{\text {tabel }}<t_{\text {hitung }}<$ $t_{\text {tabel }}$ yaitu $-1,669<2,073<1,669$ maka Ha diterima, dengan demikian diperoleh kesimpulan bahwa terdapat perbedaan peningkatan kemampuan berpikir kreatif matematis siswa menggunakan model pembelajaran kooperatif tipe berkirim salam dan soal dengan model pembelajaran kooperratif tipe Think Pair Share pada materi luas permukaan dan volume kubus dan balok di kelas VIII SMP Swata Imelda Medan T.A 2016/2017.
\end{abstract}

Kata Kunci : Model pembelajaran kooperatif tipe berkirim salam dan soal, Think Pair Share, berpikir kreatif

Sri Wahyuni Tampubolon, Edi Syahputra. Perbedaan Peningkatan Kemampuan Berpikir Kreatif Matematis Siswa Menggunakan Model Pembelajaran Kooperatif Tipe Berkirim Salam dan Soal dengan Think Pair Share di SMP Swasta Imelda Medan. Inspiratif, Vol. 3. No. 1 April 2017. 


\begin{abstract}
This study aims to see that there are differences in the improvement of students' mathematical creative thinking ability using cooperative learning model type greeting and problem with cooperative learning model Think Pair Share type on surface and volume material of cube and beam in class VIII SMP Swata Imelda Medan TA 2016 / 2017. The research is a quasi-experiment. The population in this study is all students of class VIII Semester II of Private Junior High School Imelda Medan consisting of 4 classes with total students 136 people. Sampling is done by simple random sampling by taking 2 classes from 4 classes randomly, that is experiment class 1 which is 30 people and experiment 2 class which is 34 people. The instrument used to determine students' mathematical creative thinking ability is a test of creative thinking ability that has been validated in the form of a description. From the results of the research given different treatment, experimental class 1 with cooperative learning model type send greetings and the problem and experiment class 2 with cooperative cooperative learning model Think Pair Share type obtained average grade experiment 1 of 34.375 and the average grade Experiment 2 of 25,368. Result of t test 2 direction with $d k=62$ and $\alpha=0,05$, obtained tcount $=2.073$ and ttable $=1,669$ so - ttable $<t$ count $<$ ttabel that is $-1,669<2,073$ $<1,669$ then Ha is accepted, thus obtained the conclusion that there are differences in the improvement of students' mathematical creative thinking ability using cooperative learning model type send greetings and problems with cooperative learning model Think Pair Share type on surface material and volume of cube and beam in class VIII SMP Swata Imelda Medan FY 2016/2017.
\end{abstract}

Keywords : Cooperative learning model type sends regards and matter, Think Pair Share, creative thinking

\section{Pendahuluan}

Pendidikan memegang peranan yang penting untuk menjamin kelangsungan hidup seseorang karena pendidikan merupakan tempat untuk meningkatkan dan mengembangkan kualitas Sumber Daya Manusia. Dengan pendidikan kehidupan bisa menjadi lebih baik dan lebih bermanfaat bagi orang lain. Pendidikan merupakan upaya membangun peradaban, sebagai suatu bentuk kegiatan kehidupan dalam masyarakat. Untuk mewujudkan manusia seutuhnya yang berlangsung sepanjang hayat.

Salah satu persoalan besar yang dihadapi bangsa Indonesia saat ini adalah rendahnya kualitas pendidikan nasional. Rendahnya kualitas pendidikan tersebut disebabkan oleh banyak faktor, antara lain dari peserta didiknya sendiri yang belum sadar akan pentingnya pendidikan yang akan membawa mereka ke arah yang lebih baik dan yang akan mengantarkan mereka pada kesuksesan dunia yang otomatis pendidikan akan mengantarkan mereka pada persaingan internasional.

Mata pelajaran matematika diberikan untuk membekali peserta didik dengan kemampuan berpikir logis, analitis, sistematis, kritis dan kreatif, serta kemampuan bekerjasama. Kompetensi tersebut diperlukan agar peserta didik dapat memiliki kemampuan memperoleh, mengelola, dan memanfaatkan informasi untuk bertahan hidup pada keadaan yang selalu berubah, tidak pasti dan kompetitif (Depdiknas, 2006).

Namun selama ini, proses pembelajaran matematika yang berlangsung di dalam kelas masih

Sri Wahyuni Tampubolon, Edi Syahputra. Perbedaan Peningkatan Kemampuan Berpikir Kreatif Matematis Siswa Menggunakan Model Pembelajaran Kooperatif Tipe Berkirim Salam dan Soal dengan Think Pair Share di SMP Swasta Imelda Medan. Inspiratif, Vol. 3. No. 1 April 2017. 
berpusat pada guru, guru lebih aktif bertindak sebagai pemberi informasi dan siswa hanya aktif menerima informasi dengan cara mendengarkan, mencatat atau menyalin, dan menghafal, sehingga membuat pengetahuan yang diperoleh cepat dilupakan dan tidak bermakna. Proses pembelajaran seperti ini menjadikan siswa sulit untuk mencapai hasil belajar yang optimal. Upaya yang dapat dilakukan guru untuk mencapai pembelajaran yang optimal, yaitu dengan menerapkan model pembelajaran yang baru. Menurut Suryani dan agung (2012:73):

Model pembelajaran adalah rangkaian dari pendekatan, strategi, metode, teknik, dan taktik pembelajaran. Model pembelajaran pada dasarnya merupakan bentuk pembelajaran yang tergambar dari awal sampai akhir yang disajikan secara khas oleh guru. Dengan kata lain, model pembelajaran merupakan bungkus atau bingkai dari penerapan suatu pendekatan, strategi, metode dan teknik pembelajaran.

Model pembelajaran tipe berkirim salam dan soal dikembangkan oleh Spencer Kagan dan kawan-kawan. Teknik berkirim salam dan soal memberi siswa kemampuan untuk melatih pengetahuan dan keterampilan siswa. Siswa membuat pertanyaan sendiri sehingga siswa akan lebih terdorong untuk belajar dan menjawab pertanyaan yang dibuat oleh temanteman sekelasnya. Kegiatan berkirim salam dan soal ini dapat digunakan untuk semua mata pelajaran dan untuk semua tingkatan peserta didik. Pembelajaran kooperatif tipe berkirim salam dan soal dirancang untuk mempengaruhi pola interaksi siswa, dan teknik ini memberikan siswa kesempatan untuk melatih pengetahuan dan keterampilannya, maka secara tidak langsung guru telah melibatkan siswa untuk berpartisipasi dan sekaligus telah mengaktifkan siswa dalam pembelajaran. Karena semakin banyak aktifitas yang dilakukan siswa maka kemampuan berpikir kreatif matematis siswa juga semakin baik.

$$
\text { Sedangkan Model }
$$

pembelajaran kooperatif tipe Think Pair Share memberi siswa kesempatan untuk bekerja sendiri serta bekerjasama dengan orang lain. Langkah-langkah pembelajaran kooperatif tipe Think Pair Share adalah Thinking (berpikir), Pairing (berpasangan) dan Sharing (berbagi). Adanya tahap mempresentasikan hasil kerjanya dan siswa lain memberi tanggapan terhadap hasil pekerjaan temannya dapat melatih siswa untuk mengekspresikan ide-ide matematikanya. Model pembelajaran kooperatif tipe Think Pair Share ini memberikan banyak sisa waktu untuk berpikir dan merespon serta saling membantu satu sama lain, sehingga siswa dituntut untuk berbagi informasi dengan siswa yang lainnya dan saling belajar mengajar sesama siswa dalam merespon pertanyaan yang dapat meningkatkan kemampuan berpikir mereka.

Menurut Raba (2017) :

Siswa merasa lebih nyaman jika mereka diberikan cukup waktu untuk berpikir dan mengatur pikiran mereka sebelum mereka mulai mengekspresikan diri. Itu lebih baik daripada menanggapi secara langsung. Semakin banyak waktu yang mereka pikirkan tentang hal itu, semakin sedikit kesalahan yang mereka buat.

Penerapan model pembelajaran yang bervariasi dapat mengatasi kejenuhan siswa sehingga dapat dikatakan bahwa model pembelajaran sangat berpengaruh terhadap kemampuan berpikir kreatif siswa.

Munandar (2012:32) menyatakan pentingnya pengembangan berpikir kreatif didasarkan atas empat alasan, yaitu :

Sri Wahyuni Tampubolon, Edi Syahputra. Perbedaan Peningkatan Kemampuan Berpikir Kreatif Matematis Siswa Menggunakan Model Pembelajaran Kooperatif Tipe Berkirim Salam dan Soal dengan Think Pair Share di SMP Swasta Imelda Medan. Inspiratif, Vol. 3. No. 1 April 2017. 
1. Kemampuan kreatif orang dapat mewujudkan (mengaktualisasi) dirinya sendiri;

2. Kemampuan kreatif sebagai kemampuan untuk melihat bermacam-macam kemungkinan untuk menyelesaikan suatu masalah;

3. Bersibuk diri secara kreatif tidak hanya bermanfaat, tapi juga memberi kepuasan pada individu;

4. Kemampuan kratif dapat membuat manusia mampu meningkatkan kualitas hidupnya.

Kemampuan berpikir tingkat tinggi, baik itu kemampuan berpikir kritis, kreatif serta kemampuan pemecahan masalah yang dimiliki oleh seseorang, tidak dapat dimiliki secara langsung melainkan diperoleh melalui latihan. Oleh karena kemampuan ini sangat penting, seharusnya kemampuan ini dilatih dalam semua pembelajaran di kelas. Namun, pada kenyataannya dunia pendidikan di Indonesia mainstream paradigma utama yang ada cenderung hanya memperkuat kekuatan otak kiri (intelektualitas). Sementara pengembangan otak kanan (kreativitas) masih kurang.

Masalah ini diduga disebabkan karena kemampuan berpikir tingkat tinggi termasuk berpikir kreatif jarang dilatih, karena proses pembelajaran biasanya meliputi tugas-tugas yang harus dicari suatu jawaban yang benar/berpikir konvergen (Munandar, 2012:34). Hal tersebut terjadi di SMP Swasta Imelda Medan yang dilakukan peneliti di kelas VIII menunjukkan bahwa, selama pembelajaran siswa terlihat pasif dan tidak mampu mengajukan pertanyaan dan gagasan yang beragam. Aktivitas dan kemampuan kreatif siswa terutama berikir lancar dan luwes yang masih tergolong rendah, ini terjadi karena pembelajaran yang masih berpusat pada guru.

Dari uraian di atas, penulis ingin mengetahui apakah terdapat perbedaan peningkatan kemampuan berpikir kreatif matematis siswa menggunakan model pembelajaran kooperatif tipe berkirim salam dan soal dengan model pembelajaran kooperatif tipe think pair share di SMP Swasta Imelda Medan.

\section{Metode Penelitian}

Populasi dalam penelitian ini adalah seluruh kelas VIII SMP Swasta Imelda Medan T.A 2016/2017 yang terdiri dari 4 kelas yang masing-masing kelas berjumlah rata-rata 34 siswa. Pengambilan sampel dalam penelitian ini dilakukan dengan menggunakan teknik simple random sampling yaitu pengambilan anggota sampel dari populasi yang dilakukan secara acak tanpa memperhatikan strata yang ada dalam populasi (Lestari \& Yudhanegara 2015:107).

Pengambilan sampel dilakukan seperti mengambil undian. Pengambilan undian pertama ditentukan sebagai kelas eksperimen 1 sedangkan pengambilan undian kedua ditentukan sebagai kelas eksperimen 2, sehingga diperoleh kelas VIII-A sebanyak 30 siswa sebagai kelas eksperimen 1 yang diajarkan dengan menggunakan model pembelajaran kooperatif tipe berkirim salam dan soal dan kelas VIII-C sebanyak 34 siswa sebagai kelas eksperimen 2 yang diajarkan dengan menggunakan model pembelajaran kooperatif tipe Think Pair Share.

Penelitian ini menggunakan jenis penelitian quasi eksperiment (eksperimen semu) yaitu penelitian yang mendekati penelitian true experiment dimana tidak mungkin mengadakan kontrol secara penuh terhadap variabel-variabel yang relevan. Desain penelitian yang digunakan adalah Pretest-Posttest Control

Sri Wahyuni Tampubolon, Edi Syahputra. Perbedaan Peningkatan Kemampuan Berpikir Kreatif Matematis Siswa Menggunakan Model Pembelajaran Kooperatif Tipe Berkirim Salam dan Soal dengan Think Pair Share di SMP Swasta Imelda Medan. Inspiratif, Vol. 3. No. 1 April 2017. 
Group Design yaitu eksperimen yang

dilaksanakan pada dua kelompok

Tabel 1 Desain Penelitian Two Group (Pre-test dan Post-test)

\begin{tabular}{|c|c|c|c|}
\hline Kelas & Pre-tes & Perlakuan & Post-test \\
\hline Eksperimen 1 & $\mathrm{T}_{1(\mathrm{x})}$ & $\mathrm{X}$ & $\mathrm{T}_{2(\mathrm{x})}$ \\
\hline Eksperimen 2 & $\mathrm{T}_{1(\mathrm{y})}$ & $\mathrm{Y}$ & $\mathrm{T}_{2(\mathrm{y})}$ \\
\hline
\end{tabular}

Keterangan:

$\mathrm{X} \quad$ : Perlakuan yang diberikan pada kelas eksperimen 1, yaitu dengan

Pembelajaran kooperatif tipe Berkirim Salam dan Soal.

Y : Perlakuan yang diberikan pada kelas eksperimen 2, yaitu dengan

Pembelajaran kooperatif tipe Think Pair Share.

$\mathrm{T}_{1(\mathrm{x})} \quad$ : Pemberian pre-test pada kelas eksperimen 1

$\mathrm{T}_{1(\mathrm{y})} \quad$ : Pemberian pre-test pada kelas eksperimen 2

$\mathrm{T}_{2(\mathrm{x})} \quad$ : Pemberian post-test pada kelas eksperimen 1

$\mathrm{T}_{2(\mathrm{y})} \quad$ : Pemberian post-test pada kelas eksperimen 2

Instrumen pengumpulan data melalui TKBK Pretest dan posttest. Data yang diperoleh digunakan untuk melihat terdapat peningkatan kemampuan berpikir kreatif matematis siswa menggunakan model pembelajaran berkirim salam dan soal dengan think pair share. Uji yang digunakan adalah Uji-t dua arah. Sebelum dilakukan uji-T, dilakukan uji normalitas dan homogenitas data.

62,5 , sedangkan selisih posttest-pretest terendah adalah 0 dengan nilai rata-rata selisih posttest-pretest kemampuan berpikir kreatif matematis siswa adalah 34,375 dengan simpangan baku 18,478. Sedangkan kelas eksperimen 2 yang menggunakan model pembelajaran kooperatif tipe Think Pair Share diperoleh data hasil penelitian bahwa selisih posttest-pretest tertinggi adalah 56,25 , sedangkan selisih postest-pretest terendah adalah 0 dengan nilai rata-rata selisih posttest-pretest kemampuan berpikir kreatif matematis siswa adalah 25,368 dengan simpangan baku 16,279. Dari data selisih postest-pretest diperoleh data berdistribusi normal dan homogen. diperoleh data hasil penelitian bahwa selisih posttest-pretest tertinggi adalah

Tabel.2 Ringkasan Uji Normalitas Data Selisih Postest-Pretest Siswa

\begin{tabular}{|c|c|c|c|c|}
\hline $\begin{array}{c}\text { Data } \\
\text { Pretest }\end{array}$ & Kelas & $\mathbf{L}_{\mathbf{0}}$ & $\mathbf{L}_{\text {tabel }}(\boldsymbol{\alpha}=\mathbf{0 , 0 5})$ & Kesimpulan \\
\hline 30 & Eksperimen 1 & 0,0156 & 0,030 & Normal \\
\hline 34 & Eksperimen 2 & 0,1245 & 0,1519 & Normal \\
\hline $\begin{array}{c}\text { Data } \\
\text { Posttest }\end{array}$ & Kelas & $\mathbf{L}_{\mathbf{0}}$ & $\mathbf{L}_{\text {tabel }}(\boldsymbol{\alpha}=\mathbf{0 , 0 5})$ & Kesimpulan \\
\hline 30 & Eksperimen 1 & 0,0210 & 0,030 & Normal \\
\hline 34 & Eksperimen 2 & 0,1047 & 0,1519 & Normal \\
\hline Data & Kelas & $\mathrm{L}_{0}$ & $\mathrm{~L}_{\text {tabel }}(\alpha=0,05)$ & Kesimpulan \\
\hline 36 & Eksperimen 1 & 0,13327 & 0,1476 & Normal \\
\hline 36 & Eksperimen 2 & 0,1107 & 0,1476 & Normal \\
\hline
\end{tabular}

Sri Wahyuni Tampubolon, Edi Syahputra. Perbedaan Peningkatan Kemampuan Berpikir Kreatif Matematis Siswa Menggunakan Model Pembelajaran Kooperatif Tipe Berkirim Salam dan Soal dengan Think Pair Share di SMP Swasta Imelda Medan. Inspiratif, Vol. 3. No. 1 April 2017. 
Tabel.3 Ringkasan Uji Normalitas Data Selisih Posttest-Pretest Siswa

\begin{tabular}{|c|c|c|c|c|}
\hline Data & Kelas & $\mathbf{L}_{\mathbf{0}}$ & $\mathbf{L}_{\text {tabel }}(\boldsymbol{\alpha}=\mathbf{0 , 0 5})$ & Kesimpulan \\
\hline 30 & Eksperimen 1 & 0,0085 & 0,030 & Normal \\
\hline 34 & Eksperimen 2 & 0,1076 & 0,1519 & Normal \\
\hline
\end{tabular}

Tabel 4 Ringkasan Perhitungan Uji Homogenitas

\begin{tabular}{|l|c|c|c|c|c|}
\hline \multirow{2}{*}{ Nilai } & \multicolumn{2}{|l|}{ Varians } & \multirow{2}{*}{$\mathbf{F}_{\text {hitung }}$} & $\mathbf{F}_{\text {tabel }}$ & Kesimpulan \\
\cline { 2 - 3 } & Eksperimen 1 & Eksperimen 2 & & & \\
\hline Pre-test & 107,060 & 173,396 & 0,009 & 1,29 & Homogen \\
\hline Post-test & 137,21 & 160,985 & 1,173 & 1,29 & Homogen \\
\hline Selisih & 341,460 & 265,012 & 1,288 & 1,29 & Homogen \\
\hline
\end{tabular}

Pengujian homogenitas data dilakukan untuk mengetahui apakah kelompok sampel yang digunakan dalam penelitian ini berasal dari populasi yang homogen atau tidak, artinya apakah sampel yang digunakan dapat mewakili seluruh populasi yang ada.

Berdasarkan Tabel diperoleh $\mathrm{F}_{\text {hitung }}<\mathrm{F}_{\text {tabel }}$ maka data kemampuan berpikir matematis siswa dengan menggunakan model pembelajaran kooperatif tipe berkirim salam dan soal dengan pembelajaran kooperatif tipe Think Pair Share dinyatakan memiliki varians yang sama atau homogen.

Setelah diberikan perlakuan maka diperoleh rata-rata selisih PosttestPretest kelas eksperimen 1 adalah 34,375 dan rata-rata selisih PosttestPretest kelas eksperimen 2 adalah 25,368 (Lampiran 24). Perhitungan uji hipotesis kelas eksperimen 1 dan kelas eksperimen 2 secara ringkas ditunjukkan pada tabel 5 .

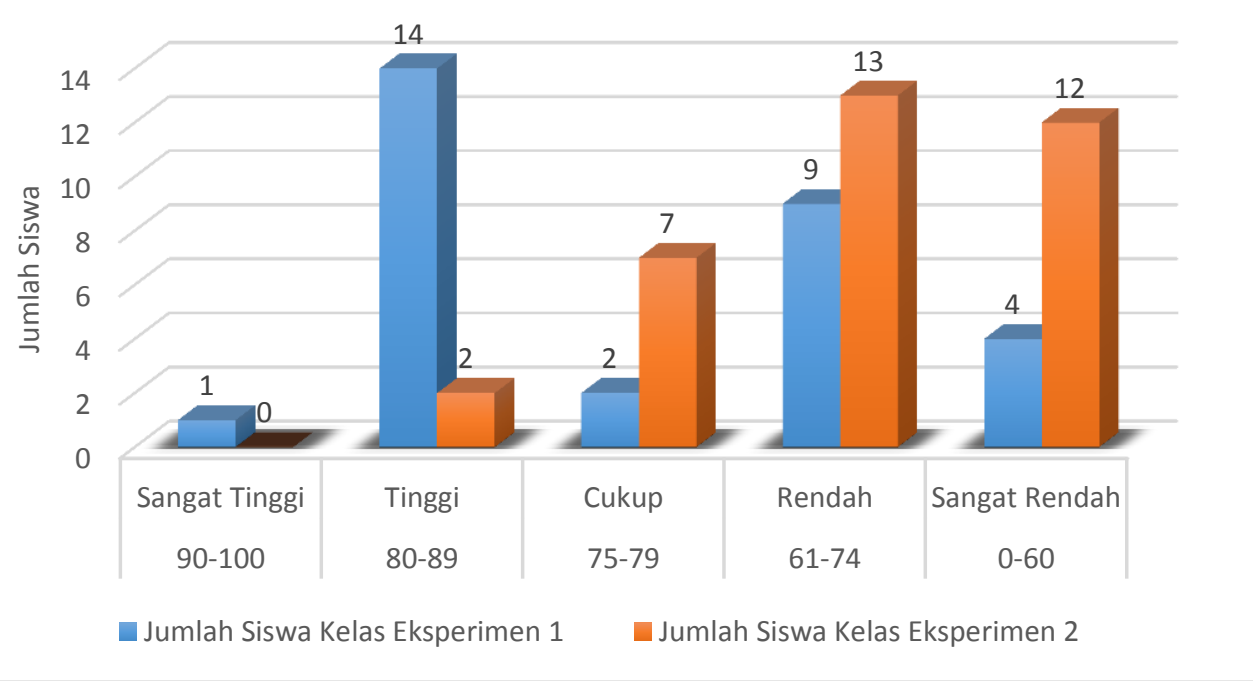

Gambar 1. Jumlah Kelas Eksprimen 1 dan 2

Dari gambar di atas dapat dilihat bahwa berdasarkan kriteria ketuntasan minimal (KKM) yang ditetapkan oleh sekolah, pada kelas eksperimen 1 yang menggunakan model pembelajaran kooperatif tipe berkirim salam dan soal diperoleh 17 dari 30 siswa atau 56,67\% siswa telah mencapai nilai KKM, dan 13

Sri Wahyuni Tampubolon, Edi Syahputra. Perbedaan Peningkatan Kemampuan Berpikir Kreatif Matematis Siswa Menggunakan Model Pembelajaran Kooperatif Tipe Berkirim Salam dan Soal dengan Think Pair Share di SMP Swasta Imelda Medan. Inspiratif, Vol. 3. No. 1 April 2017. 
dari 30 siswa atau $43,33 \%$ siswa belum mencapai nilai KKM. Sedangkan pada kelas eksperimen 2 yang menggunakan model pembelajaran kooperatif tipe Think Pair Share diperoleh 9 dari 34 siswa atau 26,47\% siswa telah mencapai nilai KKM dan 25 dari 34 siswa atau $73,53 \%$ siswa belum dapat mencapai nilai KKM. Berdasarkan nilai rata-rata siswa di kelas eksperimen 1 yaitu 74,583 terdapat 17 dari 30 siswa atau 56,67 siswa mencapai nilai di atas ratarata, dan pada kelas eksperimen 2 dengan rata-rata 62,5 terdapat 15 dari 34 siswa atau $44,12 \%$ siswa yang mencapai nilai di atas rata-rata.

Tabel 5 Ringkasan Perhitungan Uji Hipotesis Data Selisih Pretest-Posttest

\begin{tabular}{|c|c|c|c|c|}
\hline Data Kelas & $\begin{array}{c}\text { Nilai Rata-rata Selisih } \\
\text { Posttest-Pretest }\end{array}$ & $\mathbf{t}_{\text {hitung }}$ & $\mathbf{t}_{\text {tabel }}$ & Kesimpulan \\
\cline { 1 - 2 } Eksperimen 1 & 34,375 & 2,073 & 1,669 & Terima $\mathrm{H}_{\mathrm{a}}$ \\
\cline { 1 - 2 } Eksperimen 2 & 25,368 & & & \\
\hline
\end{tabular}

Berdasarkan tabel diatas hasil pengujian pada taraf signifikansi $\alpha=0,05 \mathrm{dan} \mathrm{dk}=$ $\mathrm{n}_{1}+\mathrm{n}_{2}-2=62$ dengan $\mathrm{t}_{\text {hitung }}=1,28$ dan $\mathrm{t}_{\text {tabel }}=1,29$ sehingga terlihat $t_{\text {hitung }}>$ $t_{\text {tabel }}$ yaitu $1,29>1,28$ yang berarti bahwa $\mathrm{H}_{0}$ ditolak dan $\mathrm{H}_{\mathrm{a}}$ diterima. Sehingga disimpulkan bahwa data homogen.

\section{Pembahasan Penelitian}

Mencermati hasil penelitian yang telah dikemukakan pada sub bab sebelumnya, diperoleh bahwa model pembelajaran kooperatif tipe berkirim salam dan soal (kelas eksperimen 1) dan model pembelajaran kooperatif tipe Think Pair Share (kelas eksperimen 2) memiliki perbedaan rata-rata 9,007 lebih tinggi pada kelas eksperimen 1. Dengan pembelajaran kooperatif tipe berkirim salam dan soal ini memberi siswa kesempatan untuk berlatih kemampuan berpikir kreatif, memberi siswa kesempatan untuk melatih pengetahuan dan keterampilan mereka. Siswa membuat pernyataan sendiri sehingga akan terasa lebih terdorong untuk belajar dan menjawab pertanyaan yang dibuat oleh teman-teman sekelasnya. Terlebih lagi tipe berkirim salam dan soal ini merupakan suatu metode pembelajaran yang menunjukkan kepada siswa bahwa setiap mata pelajaran hakikatnya merupakan cara berpikir. Hal ini sejalan dengan tujuan peneliti untuk mengukur peningkatan kemampuan berpikir tingkat tinggi (kreativitas) siswa. Sementara pada pembelajaran kooperatif tipe Think Pair Share memiliki prosedur yang telah ditetapkan untuk memberikan siswa kesempatan lebih banyak untuk berpikir secara sendiri, berdiskusi, saling membantu dalam kelompok, dan diberi kesempatan untuk berbagi dengan siswa yang lain. Yang menjadi kendala pada model pembelajaran TPS ini adalah siswa lebih menyukai interaksi/ kerjasama yang melibatkan banyak pihak.

Pada kelas eksperimen 1, tiap anggota kelompok beranggotakan 6 orang sehingga kegiatan diskusi dan bahan ajar terpenuhi. Slavin (dalam Trianto, 2009:56) yang menyatakan bahwa dalam belajar kooperatif siswa dibentuk dalam 5 atau 6 orang untuk bekerjasama dalam mencapai materi dan terlibat secara aktif dalam proses berpikir guna memperoleh kesimpulan yang lebih baik dari belajar secara individu atau berpasangan. Pada saat diskusi inilah siswa bebas mengeluarkan ide-ide kreatifnya dalam menyelesaikan masalah.

Kooperatif learning bernaung dalam teori konstruktivisme. Pendekatan konstruktivisme mempunyai beberapa konsep umum, di antaranya disebutkan berikut ini.

Sri Wahyuni Tampubolon, Edi Syahputra. Perbedaan Peningkatan Kemampuan Berpikir Kreatif Matematis Siswa Menggunakan Model Pembelajaran Kooperatif Tipe Berkirim Salam dan Soal dengan Think Pair Share di SMP Swasta Imelda Medan. Inspiratif, Vol. 3. No. 1 April 2017. 
1. Pelajar aktif membina pengetahuan berdasarkan pengalaman yang sudah ada.

2. Dalam konteks pembelajaran, pelajar seharusnya membina pengetahuannya sendiri.

3. Pentingnya membina pengetahuan secara aktif oleh pelajar sendiri melalui proses saling memengaruhi antara pembelajaran terdahulu dengan yang terbaru.

4. Unsur terpenting dalam teori ini adalah seseorang membina pengetahuan dirinya secara aktif dengan cara membandingkan informasi baru dengan pemahamannya yang sudah ada.

5. Ketidakseimbangan merupakan faktor motivasi pembelajaran yang utama. Faktor ini berlaku apabila seorang pelajar menyadari gagasangagasannya tidak konsisten atau bertentangan dengan pengetahuan ilmiah.

6. Bahan pengajaran yang disediakan harus berkaitan dengan pengalaman siswa untuk menarik minatnya dalam belajar.

(Asmani 2016:22)

Hasil yang diperoleh dari penelitian ini menunjukkan bahwa pembelajaran matematika dengan teknik berkirim salam dan soal dapat meningkatkan kemampuan berpikir kreatif siswa. Peningkatan kemampuan kreatif siswa di kelas VIII SMP Swasta Imelda Medan yang diajar dengan menerapkan model pembelajaran kooperatif tipe berkirim salam dan soal (eksperimen 1) memiliki perbedaan dengan model pembelajaran kooperatif tipe Think Pair Share (eksperimen 2). Dari hasil penelitian diperoleh rata-rata peningkatan hasil posttest-pretest pada kelas eksperimen 1 adalah 34,375 dan rata-rata peningkatan hasil posttestpretest pada kelas eksperimen 2 adalah 25,368 . Hal ini dibuktikan dari hasil perhitungan statistik dimana $-t_{\text {hitung }}<$ $t_{\text {tabel }}<t_{\text {hitung }}$ yaitu $-1,669<2,073<$ 1,669 yang berarti bahwa $\mathrm{H}_{\mathrm{o}}$ ditolak dan $\mathrm{H}_{\mathrm{a}}$ diterima. Sehingga disimpulkan bahwa terdapat perbedaan kemampuan berpikir kreatif matematis siswa menggunakan model pembelajaran kooperatif tipe berkirim salam dan soal dengan model pembelajaran kooperatif tipe Think Pair Share.

Hasil penelitian tersebut sejalan dengan hasil penelitian yang dilakukan oleh John B.E (2014) dengan judul "Effect of Coperative Learning Strategy on the Creative Thinking Skill of Secondary School Students of Kohikode District" . Dari hasil penelitian tersebut diperoleh kesimpulan bahwa pembelajaran dengan strategi CLS dapat meningkatkan kemampuan berpikir kreatif matematika siswa di kelas VIII. Hal ini sejalan dengan penelitian yang dilakukan oleh Wiji Nurokhman (2014) melakukan penelitian dengan judul "Eksperimentasi pembelajaran matematika model CLS dengan teknik berkirim salam dan soal SMP Negeri 3 Gombong". Dari hasil penelitian tersebut diperoleh kesimpulan bahwa prestasi belajar matematika kompetensi faktorisasi suku aljabar menggunakan model cooperative learning structures dengan teknik berkirim salam dan soal lebih baik jika dibandingkan dengan prestasi belajar matematika menggunakan model konversional pada siswa kelas VIII semester 1 SMP Negeri 3 Gombong tahun pelajaran 2013/2014. Berdasarkan perbedaan hasil penelitian rata-rata posttest-pretest masing-masig kelas eksperimen dan hasil penelitian yang relevan dapat disimpulkan bahwa terdapat perbedaan peningkatan kemampuan berpikir kreatif matematis siswa dengan menggunakan model pembelajaran kooperatif tipe berkirim salam dan soal dengan model pembelajaran kooperatif tipe Think Pair Share dengan perbedaan sebesar 9,007 lebih tinggi pada kelas eksperimen 1. 


\section{Kesimpulan dan Saran}

Dari hasil analisis yang dilakukan dalam penelitian ini diperoleh kesimpulan sebagai berikut:

1. Berdasarkan perhitungan diperoleh bahwa $t_{\text {hitung }}=2,073$ dan $t_{\text {tabel }}=$ 1,669 sehingga terlihat bahwa ternyata $t_{\text {hitung }}$ tidak berada pada interval $-1,669<t_{\text {hitung }}<1,669$ dengan $\quad t_{\text {hitung }}=2,073$ yang berarti bahwa $\mathrm{H}_{\mathrm{o}}$ ditolak dan $\mathrm{H}_{\mathrm{a}}$ diterima. Sehingga dapat disimpulkan bahwa terdapat perbedaan kemampuan berikir kreatif siswa dengan menggunakan model pembelajaran kooperatif tipe berkirim salam dan soal dengan model pembelajaran kooperatif tipe Think Pair Share di SMP Swasta Imelda Medan T.A 2016/2017.

2. Peningkatan kemampuan berpikir kreatif matematis siswa dengan menggunakan model pembelajaran kooperatif tipe berkirim salam dan soal dengan model pembelajaran kooperatif tipe Think Pair Share memiliki perbedaan rata-rata sebesar 9,007 lebih tinggi pada kelas eksperimen 1 (teknik berkirim salam dan soal).

3. Hasil peningkatan kemampuan berpikir kreatif matematis siswa yang diajar dengan model pembelajaran kooperatif tipe berkirim salam dan soal diperoleh rata-rata selisih posttest-pretest sebesar 34,375. Dari hasil yang diperoleh terlihat bahwa tipe berkirim salam dan soal memiliki peningkatan lebih tinggi dibandingkan dengan tipe Think Pair Share. Secara deskriptif diperoleh bahwa pada kelas eksperimen 1 dengan model pembelajaran kooperatif tipe berkirim salam dan soal diperoleh 17 dari $30(56,67 \%)$ siswa sudah mencapai kriteria ketuntasan minimal. Model pembelajaran
Kooperatif tipe berkirim salam dan soal dapat digunakan untuk semua mata pelajaran dan model pembelajaran ini juga efektif digunakan pada saat menjelang ujian sekolah.

4. Hasil penigkatan kemampuan berpikir kreatif matematis siswa yang diajar dengan model pembelajaran kooperatif tipe Think Pair share diperoleh rata-rata selisih posttest-pretest sebesar 25,368. Peningkatan menggunakan tipe pembelajaran ini lebih rendah dibandingkan peningkatan pada tipe pembelajaran di kelas eksperimen 1. Secara deskriptif diperoleh bahwa pada kelas eksperimen 2 dengan model pembelajaran kooperatif tipe Think Pair Share diperoleh 9 dari 34 (26,47\%) siswa sudah mampu mencapai kriteria ketuntasan minimal.

\section{Saran}

Kepada peneliti selanjutnya agar memberikan pengarahan terlebih dahulu sebelum pembelajaran dimulai kepada setiap kelompok untuk saling:

1. Berdiskusi, mengeluarkan pendapat, tukar pikiran serta menyatukan pikiran-pikiran atau ide setiap anggota kelompok untuk menyelesaikan tugas yang diberikan guru.

2. Kepada guru : Model pembelajaran kooperatif tipe berkirim salam dan soal dapat digunakan untuk semua mata pelajaran dan dapat meningkatkan kemampuan berpikir kreatif matematis siswa, sehingga guru dapat menggunakan model pembelajaran model pembelajaran kooperatif tipe berkirim salam dan soal pada saat pembelajaran agar pembelajaran lebih inovatif.

Sri Wahyuni Tampubolon, Edi Syahputra. Perbedaan Peningkatan Kemampuan Berpikir Kreatif Matematis Siswa Menggunakan Model Pembelajaran Kooperatif Tipe Berkirim Salam dan Soal dengan Think Pair Share di SMP Swasta Imelda Medan. Inspiratif, Vol. 3. No. 1 April 2017. 


\section{DAFTAR PUSTAKA}

Agus, N.A., (2008), Mudah Belajar Matematika Untuk Kelas VIII, Pusat Perbukuan, Jakarta.

Amalia,Y.,Duskri, M., Ahmad, A., (2015), Penerapan Model Eliciting Activities untuk Meningkatkan Kemampuan berpikir Kreatif Matematis dan Self Confidence Siswa SMA. Jurnal Didaktik Matematika Vol $2: 2355-4185$

Asmani, J.M., (2016), Tips Efektif Cooperative Learning, DIVA Press, Yogyakarta

Azhari, Somakim, (2013), Peningkatan Kemampuan Berpikir Kreatif Matematika Siswa Melalui Pendekatan Konstruktivisme di Kelas VII Sekolah Menengah Pertama (SMP) Negeri 2 Banyuasin III, Jurnal Pendidikan Matematika, Volume 7 No 2.

Bungin, B., (2011), Penelitian Kuantitatif, Kencana, Jakarta

Dewi, I., dan Lisiani, S., (2015), Upaya Meningkatkan Kreativitas Matematis Siswa Sekolah Menengah Pertama Negeri 5 Terbuka Medan dengan Menggunakan Modul Model Learning cycle, Jurnal Didaktik Matematika 2 : 23554185.

Duha, A.K.,Yerizon, Suherman, (2012), Penerapan Model Think Pair Share Terhadap Pemahaman Konsep, Jurnal Pendidikan Matematika Vol 1 No 1.

Fajriah, N,. Asiskawati, E., (2015), Kemampuan Berpikir Kreatif Siswa dalam Pembelajaran Matematika Menggunakan Pendekatan Pendidikan Matematika Realistik di SMP, EDU-MAT Jurnal Pendidikan Matematika, Volume 3 Nomor 2.
Fathurrohman, M., (2015), Model-Model Pembelajaran Inovatif, Arruzz Media, Jogjakarta.

Fatonah, S., Prasetyo. Z.K., (2014), Pembelajaran Sains, Ombak, Jogjakarta

Hamah, A., Muhlisrarini, (2014), Perencanaan dan Strategi Pembelajaran Matematika, Rajagrafindo Persada, Jogjakarta.

Hendriana, H., Soemarmono, U., (2014). Penilaian Pembelajaran Matematika. Refika Aditama, Bandung.

Lestari, K.E., Yudhanegara, M.R., (2015), Penelitian Pendidikan Matematika, Refika Aditama, Bandung.

Nisa, R., Musdi E., Jazwinarti, (2014), Penerapan Pembelajaran Kooperatif Tipe Think Pair Share pada Pembelajaran Matematika di Kelas XI IPS SMA Negeri 2 Padang Panjang, Jurnal Pendidikan Matematika Volume 3 No.1

Nurlela, L., Ismayati, E., (2015), Strategi Belajar Berpikir Kreatif, Ombak, Bandung.

Prasetiyo, A.D., Mubarokah, L., Berpikir Kreatif Siswa dalam Penerapan Model Pembelajaran Berdasarkan Masalah Matematika (Studen's Creative thinking in the Aplication of Mathematical Problems Based Learning), Jurnal Pendidikan Matematika STKIP PGRI Sidoarjo : 2337-8166 Vol.2 No.1

Raba, A. A.A., (2017), The Influence of Think-Pair-Share (TPS) on Improving Students' Oral Communication Skills in EFL Classrooms, Scientific Research Publishing 8: 2152-4771.

Sri Wahyuni Tampubolon, Edi Syahputra. Perbedaan Peningkatan Kemampuan Berpikir Kreatif Matematis Siswa Menggunakan Model Pembelajaran Kooperatif Tipe Berkirim Salam dan Soal dengan Think Pair Share di SMP Swasta Imelda Medan. Inspiratif, Vol. 3. No. 1 April 2017. 
Rahadian, S., Yerizon, Arnellius, (2012), Penerapan Kooperatif Tipe Think Pair Share dalam Pembelajaran Matematika, Jurnal Pendidikan Matematika, part 3. Vol.1 No.1

Rosita, Leonard, - , Meningkatkan Kerja Sama Siswa Melalui Pembelajaran Kooperatif Tipe Think Pair Share, Jurnal Formatif 3 : 2088-351X

Shadiq,F., (2014), Strategi Pemodelan pada Pemecahan Masalah Matematika, Graha Ilmu, Yogyakarta.

Siswono, T.Y.E., (2011), Level of Student's Creative Thinking in Classroom Mathematics, Educational Research and review Vol 6 : 1990-3839.

Sriwongchai, A., Jantharajit, N., and Chookhampaeng, S., (2015), Developing the Mathematics Learning Management Model for Improving creative Thinking in Thailand, International Education Studies vol 8: 1913-9039.

Sudijono. A., (2012), Statistik Pendidikan. Rajagrafindo Persada, Jakarta.

Sudjana, (2005), Metoda Statistika, Tarsito, Jakarta.

Sugiharti, E., and Suyitno, A.,(2015), Improving of Problem Solving
Ability of Senior High School Strudents Through Aplication of TPS Based on E-learning in Mathematics Lesson, International Journal of Education and Research 3 : 2201-6740.

Suharjito, D., (2014), Pengantar Metodologi Penelitian, IPB Press, Jakarta.

Suryani, N., Agung, L.A., (2012), Strategi Belajar-Mengajar, Ombak, Jakarta.

Suryani, Hendryani, (2015), Metode Riset Kuantitatif : Teori dan Aplikasi ada Penelitian Bidang Manajeman dan Ekonomi Islam, Fajar Interpratama Mandiri, Jakarta.

Tint, S.S., and Nyunt, E.E., (2015), Collaborative Learning With Think-Pair-Share Technique, CAIJ vol.2, no.1.

Trianto, (2011), Mendesain Model Pembelajaran InovatifProgresif Konsep Landasan dan Implementasinya pada Kurikulum Tingkat Satuan Pendidikan (KTSP), Kencana Predana Media Group, Jakarta.

Triyono, (2012), Metodologi Penelitian Pendidikan, Yogyakarta. 
